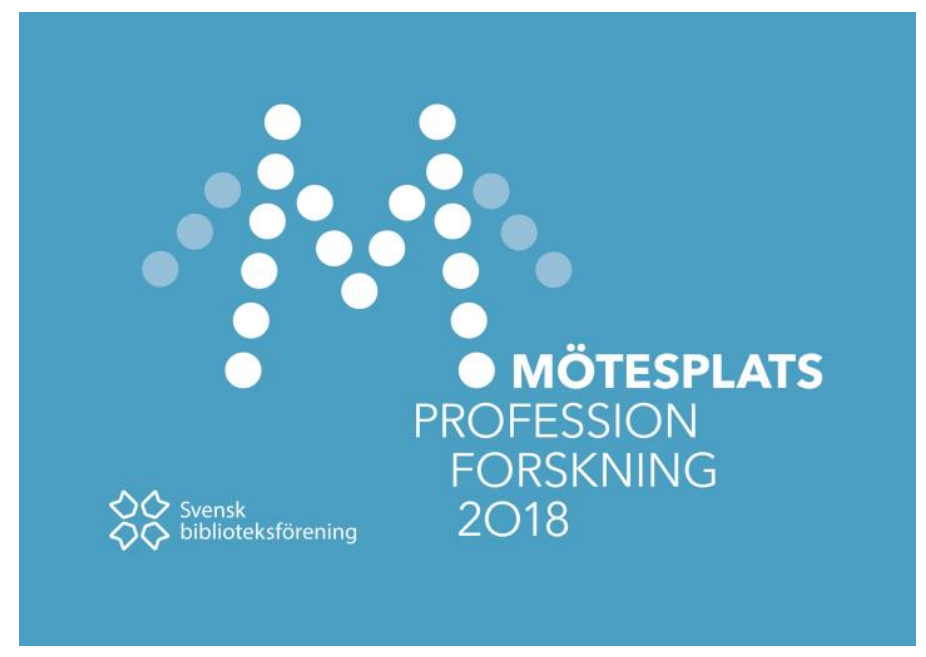

Ulrika Boström, Emmelie Ernst, Therése Haglind

Erik Dahlbergsgymnasiet, Jönköpings kommun

ulrika.bostrom@jonkoping.se,emmelie.ernst@jonkoping.se, therese.haglind@jonkoping.se

\title{
Pedagogiskt centrum - en modell för samverkan och kommunikation
}

\section{Inledning}

Dagens samhälle beskrivs som ett digitalt samhälle, ett informationssamhälle eller ett kunskapssamhälle (Burke, 2012; Guribye, 2005; Warschauer \& Matuchniak, 2010). Den förändring som skett påverkar alla delar av samhället inklusive arbetsliv, skola och fritid. I det digitala samhället har det uppstått digitala klyftor. Från början handlade det mest om vem som hade tillgång till digital teknik och vem som inte hade det. Idag talas det om "a second digital divide" som även omfattar elevers förmåga att använda digitala resurser och hur deras supportnät för användningen av digitala resurser ser ut. Skolans kompensatoriska uppdrag blir en viktig del i detta sammanhang (Warschauer, 2010; Warschauer, 2002). Digital kompetens är en av EU:s åtta nyckelkompetenser och det är ett viktigt område för skolan vilket också innebär utmaningar. Att använda sig av IT i skolan har blivit ett högprioriterat område både nationellt och internationellt (Skolverket, 2010). EU:s nyckelkompetenser har varit en av utgångspunkterna för skrivningar i den svenska läroplanen och i ämnesplanerna, vilket har resulterat i fyra aspekter av digital kompetens;

- Att förstå digitaliseringens påverkan på samhället

- Att kunna använda och förstå digitala verktyg och medier

- Att ha ett kritiskt och ansvarsfullt förhållningssätt

- Att kunna lösa problem och omsätta idéer i handling (Skolverket, 2017)

Enligt gällande läroplan ska elever i gymnasieskolan ha tillgång till skolbibliotek (Skolverket, 2017). Det står att "skolbibliotekets verksamhet används som en del i undervisningen och för att stärka elevernas språkliga och digitala kompetens" (Skolverket, 2018, s. 13). Detta ställer krav på skolan och skolans verksamhet. Skolbibliotekets viktiga roll lyfts i flera andra 
sammanhang kring skolans digitalisering. I Nationell digitaliseringsstrategi för skolväsendet (Utbildningsdepartementet, 2017) står det till exempel att "Skolbiblioteket har en viktig pedagogisk uppgift att fylla när det gäller att stärka elevers kompetenser i bland annat informationssökning och källkritik" (s.8).

Erfarenheten och forskningen visar enligt IFLA:s/Unescos skolbiblioteksmanifest (1999) och IFLA:s riktlinjer för skolbibliotek (2015) att elevers förmåga att skriva, lösa problem, läsa och använda informationsteknik förbättras när lärare och yrkesutbildade bibliotekarier samverkar. Förutom samverkan mellan bibliotekarier och lärare är det viktigt att bibliotekarierna arbetar pedagogiskt utåt i verksamheten och håller i lärande- och undervisningsaktiviteter. Undervisningen bör ske både gemensamt i grupper men även individuellt och ska vara kopplade till lärandemålen och läroplansinnehållet.

\section{Bakgrund}

Skolinspektionen (2018) och IFLA:s riktlinjer för skolbibliotek (2015) lyfter vikten av att det sker en samverkan mellan lärare och skolbibliotekarier, att skolbiblioteket har legitimitet i skolan, samt att det finns ett stöd från skolledningen. Erik Dahlbergsgymnasiets skolledning såg att det fanns ett behov att öka samverkan, samla resurser och utbilda i digitalisering. Skolan hade även fått de ekonomiska förutsättningarna för att kunna genomföra dessa satsningar. Biblioteket i samråd med skolledningen påbörjade ett utvecklingsarbete som resulterade i skapandet av ett Pedagogiskt centrum där flera olika kompetenser samlades inom information, läsfrämjande, IKT och MIK. Begreppet MIK inkluderar flertalet färdigheter som en individ behöver besitta för att kunna vara delaktig i det digitala samhället. Till dessa färdigheter räknas informationskompetens eller digital kompetens, som beskriver kunskapen att kunna söka, finna, kritiskt granska och använda information i olika sammanhang och syften (Rivano, Eckerdal \& Sundin, 2014). MIK delas ofta upp i två delar; mediekunnighet och informationskunnighet, där mediekunnighet fokuserar på medier, framförallt massmedier, och deras funktion i samhället. Informationskunnighet fokuserar på informationssökningsprocesser, alltså hur personer söker information (ibid). IKT är ett samlingsbegrepp som beskriver användning av digitala verktyg när det gäller databehandling och kommunikation. Begreppet används ofta i skolsammanhang men finns inte i läro- och ämnesplaner (Skolverket, 2017).

\section{Syftet och frågeställningar}

Syftet med konferensbidraget är att visa på ett utvecklat samarbete mellan lärare och bibliotek. Detta görs med hjälp av följande frågeställningar:

1. Vad är Pedagogiskt centrum?

2. Vilka effekter och utvecklingsområden har pedagogiskt centrum gett upphov till i verksamheten? 


\section{Metod}

Detta paper utgår ifrån ett utvecklingsarbete som genomförs på en skola i Jönköping. Jönköping är en medelstor kommun i södra Sverige med fyra kommunala gymnasieskolor där Erik Dahlbergsgymnasiet på cirka 1500 gymnasieelever är den största. Skolan har både högskoleföreberande och yrkesförberedandeprogram och ligger centralt i Jönköping. Personalstyrkan består av ungefär 150 personer varav 120 arbetar som lärare. På skolans bibliotek arbetar två heltidsbibliotekarier med olika fokusområden; Informations- och kommunikationsteknik (IKT) och allmän inriktning och pedagogik. Biblioteket har för andra året i rad blivit utsett till ett skolbibliotek i världsklass (DIK, 2018). Biblioteket är en del av skolans Pedagogiska centrum.

Datamaterialet består av diskussionsunderlag, protokoll och andra insamlade dokument såsom "röster från verksamheten". "Röster från verksamheten" är en datainsamling där ITpedagoger, lektor, bibliotekarierna och försteläraren i svenska fick i uppdrag att skriftligen besvara nedanstående tre frågor.

1. Upplever du att det finns gynnsamma effekter hos eleverna/ för eleverna med att skolan har ett pedagogiskt centrum.

2. Ser du något ytterligare behov?

3. Är det något som du skulle vilka utveckla eller ändra på?

\section{Resultat}

Resultatdelen består av två delar; Vad är pedagogiskt centrum? och Röster från verksamheten.

\section{Vad är pedagogiskt centrum?}

Pedagogiskt centrum innefattar biblioteket som fysiskt rum, bibliotekarier, IT-pedagoger, lektor samt utbildningsledare. Dessa resurser är valda utifrån sin kompetens inom IKT, MIK och lärande.

\section{Syfte med Pedagogiskt centrum:}

Nedanstående punkter finns i syftesbeskrivningen för Pedagogiskt centrum:

- Arbeta för att ge grundläggande medie- och informationskompetens hos elever och lärare.

- Arbeta för effektivt resursutnyttjande av skolans resurser i form av fysiskt och digitalt material.

- Vara ett centrum för studieteknisk kunskap/ organisation, analog och digital.

- Ordna workshops och föreläsningar inom ovanstående områden, både med interna och externa ledare, (t ex källkritik, gymnasiearbetesteknik, etik på nätet och IKT i undervisningen).

- Initiera till det kollegiala lärandet genom delaktighet i ämneslag/ arbetslag/kurser.

- Komplettera lärarna i kurser. 
Pedagogiskt centrum har en direktkanal till ledningen i form av skolans utbildningsledare och därmed en direktkanal till all personal. Utbildningsledaren är sammankallande och ansvarar för protokoll. Denna direktkanal möjliggör snabb anpassning att möta de behov som uppkommer. Pedagogiskt centrum har varit under uppbyggnad de senaste två åren. Ett strukturerat arbete har bidragit till att det nu finns rutiner och medlemmarnas olika roller är tydliggjorda samt att Pedagogiskt centrum har blivit en del av skolans organisation.

\section{Organisationsöversikt}

Organisationsöversikten nedan (bild 1) visar strukturen för Pedagogiskt centrum. Pilarna står för kommunikationen mellan de olika delarna.

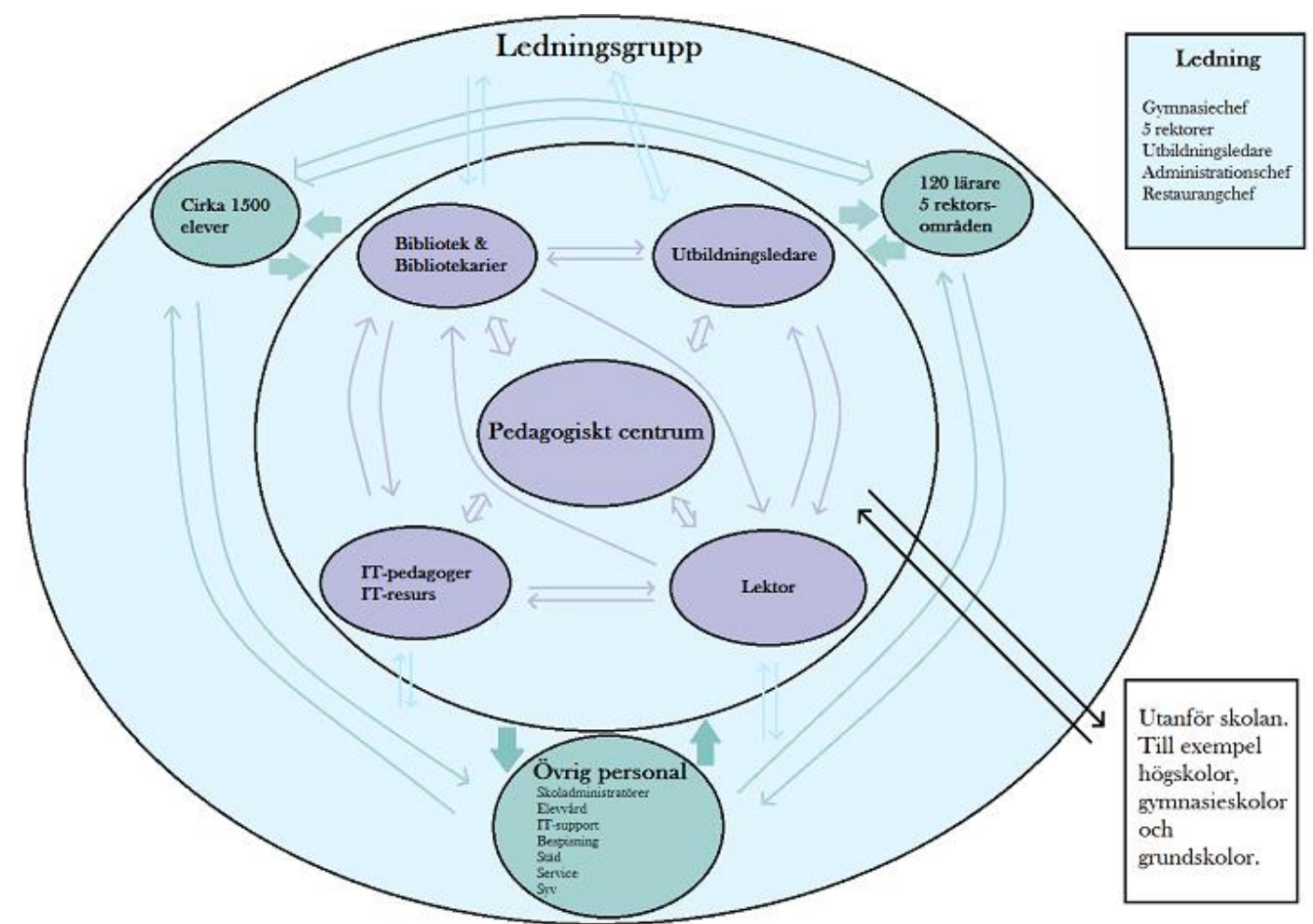

Bild 1. Organisationsöversikt ED

\section{Kompetenser inom pedagogiskt centrum}

Det finns två bibliotekarier knutna till Pedagogiskt centrum, den ena har inriktning mot IKT och den andra har en mer allmän och pedagogisk inriktning. I rollen som bibliotekarie med IKT-inriktning ingår att arbeta med utvecklingen av de digitala biblioteksresurserna. Ett av uppdragen är att utöka bibliotekets digitala medier och integrera digitala pedagogiska resurser i den fysiska skolbiblioteksmiljön, vilket bland annat innebär att biblioteket tillhandahåller flertalet digitala hjälpmedel så som mikrofoner, kameror, stativ, diktafoner med mera. Dessa integreras även i undervisningen då de bland annat används $i$ dokumentärfilmsprojektet ${ }^{1}$. Ett annat av uppdragen är att vidareutveckla skolans bibliotekstjänster inom IKT-området. Detta innebär bland annat att driva en biblioteksblogg

\footnotetext{
${ }^{1}$ Dokumentärfilmsprojektet är ett projekt som genomförs i årskurs 1 där eleverna spelar in sina egna dokumentärfilmer och tränas i att hantera digitala medier, källkritik och ämnesområdet språksociologi.
} 
och att arbeta med bibliotekssidan på skolans lärplattform. Där läggs det in länkar för olika ämnen, tips på hur du refererar till olika typer av medier, information om källkritik, länk till bibliotekets databaser med mera.

Annat som ingår i tjänsten som IKT bibliotekarie är att vara redaktör för skolans Instagram samt publicera nyheter på skolans hemsida. Bibliotekarien med IKT inriktning ansvarar för skolans läromedelshantering, vilket innebär att beställa och registrera skolans fysiska såväl som digitala läromedel. Att marknadsföra biblioteket som en arena för pedagogiskt utbyte och främja läslusten hos skolans elever ingår också i denna tjänst. Att främja läslusten sker bland annat genom arrangerandet av författarbesök, bokprat och högläsning.

I rollen som skolbibliotekarie med allmän och pedagogisk inriktning ingår bland annat huvudansvar för själva biblioteket med inköps- och budgetansvar samt det löpande arbetet i biblioteket. Nyhetsbrev och presentationer av vad som är nyinköpt hamnar också här. Att stötta, hjälpa och vägleda eleverna i deras arbeten är såklart den viktigaste uppgiften för båda bibliotekarierna, och även att ge service till lärare och övrig personal med olika typer av litteratur. Den pedagogiska rollen blir allt viktigare och tar mer och mer utrymme och numera nås i stort sett alla skolans elever med undervisning i källkritik och sökvägar/sökstrategier. Eleverna får också en introduktion till biblioteket och vad det har att erbjuda. Lärarna kan även boka bibliotekarierna för andra lektioner, till exempel $\mathrm{i}$ källhantering, informationssökning och bokprat. Regelbundna besök görs till ämneslag som vill få presentationer av nyinköpt litteratur. Bibliotekarierna samverkar i sina olika roller och till viss del går tjänsterna in i varandra.

I Pedagogiskt centrum arbetar även en lektor i tillämpad IT med inriktning mot svenska. Lektors uppdrag innefattar att vara med i både uppbyggnad och uppstart av Pedagogiskt centrum. Rollen som lektor handlar om att identifiera pedagogiska utvecklingsbehov och utvecklingsområden, både kopplat till ämnet svenska med inriktning tillämpad IT, men även övergripande skolutveckling generellt. Uppdraget innefattar att initiera och dokumentera skolutvecklingsprojekt på skolan samt att sprida erfarenheter av dessa, både internt och externt. Lektors roll i pedagogiskt centrum är främst att identifiera, strukturera och organisera. I första hand arbete med strukturer på lärarnivå, som sedan genomförs tillsammans med elever.

Utöver bibliotekarier och lektor arbetar även två IT-pedagoger i biblioteket. IT-pedagogernas uppdrag består av att vara drivande i skolans pedagogiska IKT-utveckling. De ansvarar bland annat för utveckling och utbildning inom skolans lärplattform och är administratörer för plattformen. IT-pedagogerna håller sig uppdaterade när det gäller det senaste inom den IKTpedagogiska utvecklingen och är drivande i arbetet med hur IKT leder till ökad måluppfyllelse. De har även ansvar för mjukvaror och synliggör vilka licenser och program som finns tillgängliga inom skolan och kommunen.

\section{Röster från verksamheten}

\section{IT-pedagog}

"I min roll som IT-pedagog ser jag med som ett stöd till såväl lärare som elever gällande olika problem som de stöter på i sin vardag. Jag ska finns till hjälp i det vardagliga arbetet, en möjlighet för lärare att optimera sitt arbete och bidra till en bättre arbetssituation. Effekterna kanske är svårare att ta på, eller att konkret mäta. Men det skapar kanske en 
trygghet för alla på skolan, då de vet att det finns någon att gå till när det strular. Den utveckling som jag anser behövs är att bli bättre på att involvera eleverna, att det finns några som arbetar som "coacher" gentemot mot andra elever. Sen skulle vi kunna bli bättre på att inspirera lärare att själva upptäcka nya IT-lösningar."

\section{Lektor}

"Fördelarna med Pedagogiskt centrum är flera. Framförallt vill jag lyfta styrkan i att samla resurser och kompetenser på ett ställe. Att rent fysiskt placera medlemmarna till skolans bibliotek delar av tiden underlättar för samarbetet och manifesterar vikten av att knyta samman skolbiblioteket med skolans övriga pedagogiska verksamhet. Som lektor är jag med i skolutvecklingsprojekt, som tillexempel Dokumentärfilmsprojektet. Det finns många fördelar med skolutvecklingsprojekt som både är lineära och iterativa. En tydlig fördel som jag kopplar till Pedagogiskt centrum är att projekten både testar strukturer och identifierar utvecklingsområden och framgångsfaktorer. Min uppfattning är att de resurser som finns inom pedagogiskt centrum och de lite större skolutvecklingsprojekt som genomförs på skolan är kopplade till ämnet svenska. Här ser jag ett viktigt utvecklingsområde kring att inkludera fler ämnen på olika sätt och knyta andra ämnesprojekt eller skolutvecklingsprojekt på skolan till Pedagogiskt Centrum."

\section{Bibliotekarie allmän/pedagogisk}

"Den stora fördelen med pedagogiskt centrum är att fler "övriga" pedagogiska funktioner samlas och får en betydligt starkare plattform att agera ifrån än om vi hade jobbat var för sig. Kommunikationen mellan oss, ledning, lärare, elever och övrig personal har genom p. c [Pedagogiskt centrum]. blivit enklare och tydligare. Inom gruppen har vi också fătt bättre möjligheter att bolla idéer mellan oss och dessutom har vi fått betydligt enklare att genomföra dem. För mig som har jobbat här i 20 år är skillnaden markant. På vår skola finns både stöd från skolledningen och därmed har också Pedagogiskt centrum fått legitimitet. Samverkan mellan personerna i p c. och mellan p c. och övrig personal har ökat efter hand sen uppstart."

\section{Bibliotekarie IKT}

“Fördelarna med Pedagogiskt centrum är många. Framförallt ser jag en stor fördel i att samla flera olika kompetenser i en och samma grupp. I och med att gruppen består av så många olika kompetenser kan de finnas tillhands för både elever och lärare inom flera olika områden såsom undervisning i källkritik, informationssökning, videoredigering med mera. Flera av medlemmarna arbetar även som lärare vilket gör att de har en god insyn i hur lärare arbetar och vad de är i behov av. Att ha en grupp på skolan som arbetar kring pedagogik och digitalisering gör att det finns någonstans att vända sig när man behöver hjälp. Att det dessutom finns en lektor i gruppen som kan bidra med kunskapen kring forskningen inom området gör att de får mer belägg för det de gör och att de hela tiden kan utvecklas och arbeta framåt. Ett utvecklingsområde för pedagogiskt centrum är att utvärdera verksamheten och att skapa en tydligare arbetsstruktur."

\section{Förstelärare i svenska}

“Pedagogiskt centrum säkrar upp expertisen på skolan. Att kunna uppmana och skicka eleverna till våra kunniga bibliotekarier och IT-pedagoger i ärenden där vi lärare inte är experter är en tillgång och stärker skolans professionella intryck. Vi har ett nära samarbete där vi ber dessa resurspersoner att medverka på ämneskonferenser, jag som förstelärare för 
en ständig dialog kring hur vi kan vidareutveckla samarbete och underlätta för både oss lärare och eleverna. Att vi har en lektor som i gruppen fördjupar våra kunskaper genom att vi systematiskt beforskar inom vår verksamhet där fokus ligger på digitalisering ökar våra kunskaper och stärker ämneslaget som kollektiv. Ytterligare behov är att fortsätta vårt samarbete kring gemensamma projekt där vi tar olika ansvar utifrån våra positioner. Nedan finns exempel där vi redan samarbetar:

- Biblioteksinformation för nya elever

- Källkritik och sökteknik

- Dokumentärfilmsprojektet (it-pedagogsstöd, utlåning av material osv)

- Utlåning av datorer, material till filminspelning, bokvagnar när vi har specialfokus på något område.

- Författarbesöket

- Boktips för lärare och elever

- Högläsning

- Hur vi samarbetar med elever i behov av särskilt stöd när det gäller läsning och skrivning.

Utvecklingsområde är att vi gärna vill att IT-pedagogerna svarar mot våra behov av ökat digital användning och stöd $\mathrm{i}$ undervisningen, $\mathrm{t}$ ex genom att komma på våra ämneslag och lära ut viktiga program för presentation och elevinteraktion såsom Onenote Classroom och Audicity. Att bibliotekarierna fortsätter att anpassa ämnesinnehåll till de ämnesområden som lärare arbetar med för tillfället, $t$ ex sökningar inom nordiska språk om de ska föreläsa om sökteknik och källkritik. Inköp av Ipads för utlån när eleverna ska redigera film och poddar samt att vi alla, både lärare och pedagogiska teamet [Pedagogiskt centrum] deltar i utbildning i dessa program. /.../"

\section{Sammanfattning av resultat}

Sammanfattningsvis visar resultatet på att samverkan mellan de olika funktionerna i Pedagogiskt centrum har ökat. Biblioteket arbetar mer utåtriktat och uppsökande, ITpedagogerna har ett tydligare uppdrag och lektor bidrar med forskning. Resultatet visar också på att dokumentärfilmsprojektet har ställt krav på verksamheten och i och med det har vissa funktioner efterfrågats och rollerna har tydliggjorts. Något som framkommer som ett utvecklingsområde är att samverka med flera ämnen än svenska.

I resultatet framkommer det att Pedagogiskt centrum har bidragit till att biblioteket har förflyttats från att arbeta mycket i det fysiska biblioteket till att arbeta mer uppsökande i skolan såväl fysiskt som digitalt. Dels att bibliotekarierna är ute mer i klassrummen och undervisar men likaväl att bibliotekarierna utnyttjar de digitala möjligheter som idag finns. De digitala möjligheterna utnyttjas genom att biblioteket bland annat publicerar nyheter, länktips och information på Vklass, driver i en biblioteksblogg med mera.

En fördel med Pedagogiskt centrum som framkommer i resultatet är att övriga pedagogiska funktioner på skolan samlas på ett ställe, vilket underlättar samverkan inom såväl som utanför Pedagogiskt centrum. Personalen vet var de kan vända sig om de har frågor som rör lektioner inom IKT, där både bibliotekarier och IT-pedagoger kan bistå med hjälp inom sina expertområden, eller övriga pedagogiska frågor. Att Pedagogiskt centrum är en verksamhet i rörelse som ständigt utvecklas är en annan fördel som framkommer. 


\section{Slutsatser och diskussion}

Pedagogiskt centrum är en dynamisk verksamhet som ständigt arbetar framåt för att förbättras och utvecklas. Ett led i att förbättra verksamheten är att göra utvärderingar. I IFLA:s riktlinjer för skolbibliotek (2015) står det att läsa att en viktig del av skolbiblioteksutvecklingen är att utvärdera skolbibliotekets program och tjänster. Dessa riktlinjer är tillämpbara på Pedagogiskt centrum. En utvärdering fungerar som en redovisning på att skolbibliotekets program och tjänster motsvarar verksamhetens behov. Utvärderingar bör även bidra till den pågående utvecklingen av skolbiblioteket genom att förstärka elever och lärares stöd för och tankar kring skolbiblioteket. Det är i och med det här viktigt att utvärderingen är en integrerad del av skolans kvalitetsarbete (IFLA:s riktlinjer för skolbibliotek, 2015). Skolinspektionen (2018) slår också fast att "Skolbibliotekens verksamhet behöver synliggöras och utvecklas som en del av det systematiska kvalitetsarbetet" (s. 12). Ett av de mål som Pedagogiskt centrum vill arbeta med framåt är att vara med i skolans ordinarie kvalitetsarbete - det lokala såväl som det stora kommunala. I linje med många andra skolor har Erik Dahlbergsgymnasiet en skolbiblioteksplan som i dagsläget är frikopplad med skolans övergripande kvalitetsarbete och målet är att denna ska integreras i skolans kvalitetsarbete.

De program och tjänster som ges tillgång till via skolbiblioteket bör skolbibliotekarierna utveckla tillsammans med lärarkollegor, ledningen, IT-pedagoger och annan personal för att bidra till ett så brett och välutvecklat bestånd som möjligt som kan bidra till elevers måluppfyllelse (IFLA:s riktlinjer för skolbibliotek, 2015).

Något som visat sig är att kanalerna och kommunikationen har blivit smidigare sedan uppbyggnaden av Pedagogiskt centrum. Den utåtriktade och uppsökande verksamheten har ökat både inom den egna verksamheten, men även utanför skolan. Genom Pedagogiskt centrum har bibliotekariernas lektionsbesök ökat. Medverkande i Pedagogiskt centrum har även börjat besöka grupper utanför skolan bland annat ämnesnätverket svenska (både kommunala men även det lokala), Junedalskolan i Jönköping och Högskolan i Jönköping.

Som forskning och även resultatet visar behöver Pedagogiskt centrum göra fler utvärderingar av sin verksamhet. Ett mål för framtiden är att skapa en tydligare struktur för Pedagogiskt centrum mötena, där tanken är att gå tydligare från planering till genomförande (se bild nedan).

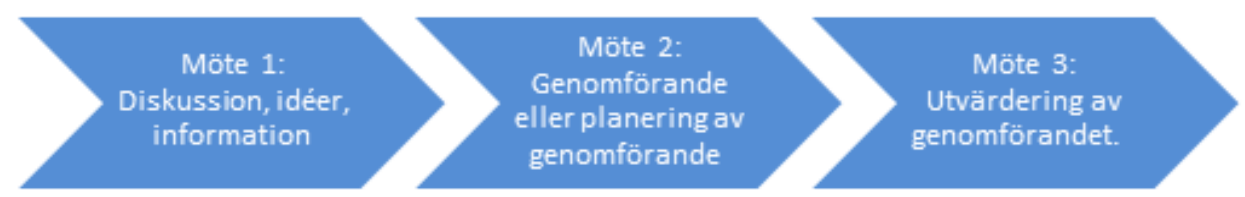

Bild 2. Mötesstruktur Pedagogiskt Centrum

En reglerad mötesstruktur underlättar ett utvecklingsarbete i gruppen, där arbetets delar blir tydligare och därmed rollfördelningen. Mötesstrukturen bidrar även till att på ett systematiskt sätt genomföra förändringsarbete.

Ett annat mål är att genomföra en undersökning som riktar sig till lärarna på skolan för att studera hur lärarna uppfattar samarbetet mellan Pedagogiskt centrum och pedagogerna. Att utveckla vidare är att skapa olika former för dokumentation och spridning som stärker verksamheten och bidrar till att skolan vilar på beprövad erfarenhet och vetenskaplig grund. 


\section{Käll- och litteraturförteckning}

Burke, P. (2012). A Social History of Knowledge, Volume II, From Encyclopedie to Wikipedia. Cambridge: Polity Press.

DIK. (2018). Här finns skolbiblioteken som håller världsklass. Hämtad 2018-04-11 från https://www.dik.se/om-dik/ovrigt/nyhetsarkiv/har-finns-skolbiblioteken-som-hallervarldsklass/.

Guribye, F. (2005). Infrastructures for learning: Ethnographic inquiries into the social and technical conditions of education and training. (Doktorsavhandling, Department of Information Science and Media Studies, University of Bergen). Tillgänglig:

https://bora.uib.no/handle/1956/859.

International Federation of Library Associations (IFLA). (2015). IFLA:s riktlinjer för skolbibliotek. Hämtad 2018-08-28 från https://www.biblioteksforeningen.se/wpcontent/uploads/2017/01/iflas-riktlinjer-for-skolbibliotek2.pdf

International Federation of Library Associations (IFLA) \& Unesco. (1999). IFLA:s/Unescos skolbiblioteksmanifest. Hämtad 2018-08-28 från https://www.biblioteksforeningen.se/wpcontent/uploads/2017/01/bibliotekens-internationella-manifest-webb-utskrift.pdf

Limberg, L., \& Lundh, A. Hampson, red. (2013). Skolbibliotekets roller i förändrade landskap. Lund: BTJ Förlag.

Rivano Eckerdal, J., \& Sundin, O. (red.). (2014). Media och informationskunnighet - en forskningsantologi. Stockholm: Svensk Biblioteksförening.

Skolinspektionen. (2018). Skolbiblioteket som pedagogisk resurs. Hämtad från https://www.skolinspektionen.se/globalassets/publikationssok/granskningsrapporter/kvalit etsgranskningar/2018/skolbibliotek/skolbiblioteket-som-pedagogisk-resursskolinspektionen-2018.pdf

Skolverket. (2018). Läroplan för gymnasieskolan. Hämtad 2018-09-05 från https://www.skolverket.se/undervisning/gymnasieskolan/laroplan-program-och-amnen-igymnasieskolan/laroplan-gy11-for-gymnasieskolan.

Skolverket. (2017). Få syn på digitaliseringen på gymnasial nivå. - Ett kommentarmaterial för gymnasieskolan, gymnasiesärskolan samt komvux och särvux på gymnasial nivå. Hämtad 2018-04-03 från https://www.skolverket.se/publikationer?id=3784.

Skolverket. (2010). Skolverkets lägesbedömning. Del 2 - bedömning och slutsatser. Rapport 350. Hämtad 2013-01-21 från http://www.skolverket.se/publikationer.

Warschauer, M. (2010). Digital divide. Encyclopedia of Library and Information Sciences, Third Edition, 1:1, 1551-1156. doi: 10.1081/E-ELIS3-120043692.

Warschauer, M. (2002). Reconceptualizing the Digital Divide. First Monday. vol 7, Nr 7, 200207-01. 